\title{
ABSTRAK \\ QUANTUM LEARNING DALAM KAJIAN MATEMATIKA SMA PADA MAHASISWA SEMESTER IV PENDIDIKAN MATEMATIKA IAIN AMBON
}

\author{
Abdillah, Dosen Prodi Pendidikan Matematika IAIN,Ambon \\ 085243478643, E-mail: abdillahji@yahoo.co.id
}

\begin{abstract}
Penelitian ini adalah penelitian tindakan kelas (classroom action research) yang bertujuan untuk meningkatkan pemahaman materi kuliah kajian matematika SMA pada mahasiswa semester IV Pendidikan Matematika IAIN Ambon melalui penerapan Quantum Learning. Berdasarkan hasil analisis data yang diperoleh dapat disimpulkan bahwa secara kualitatif, terjadi beberapa perubahan. Mahasiswa menunjukkan sikap antusias untuk mengikuti pembelajaran, serta minat dan motivasi belajar kajian matematika SMA mengalami peningkatan. Sedangkan secara kuantitatif, terjadi peningkatan skor rata-rata hasil belajar mahasiswa yaitu pada siklus I sebesar 7,18 dengan standar deviasi 1,09 menjadi sebesar 8,17 dengan standar deviasi 0,91 pada siklus II. Hal tersebut berarti terjadi peningkatan pemahaman kajian matematika SMA mahasiswa semester IV Pendidikan Matematika IAIN Ambon dengan menerapkan Quantum Learning.
\end{abstract}

Kata kunci: quantum learning, matematika SMA

\section{QUANTUM LEARNING IN MATH STUDY SENIOR HIGH SCHOOL STUDENTS ON SEMESTER IV MATHEMATICS EDUCATION IAIN}

This research is research the act of a class (classroom action research) that aims to improve understanding matter college studies mathematics high school in student semester IV math education in IAIN Ambon through the application of quantum learning. Based on the result analysis of data obtained can be concluded that, in a qualitative manner the happening of some changes. Students reveals the attitudes of learning, enthusiastic to follow and interest and motivation learn mathematics high school study is increasing. In a quantitative manner, while increase the average score study result of the students in the cycle of I as much as 7,18 with standard deviations 1,09 the size of 8,17 with standard deviations 0,91 in cycles II. It could mean increase understanding studies mathematics high school student semester IV math education in IAIN Ambon by applying quantum learning

Keywords: quantum learning, mathematics in high school. 
Dunia pendidikan saat ini sering dikritik oleh masyarakat yang disebabkan karena adanya sejumlah pelajar dan lulusan pendidikan tersebut yang menunjukkan sikap yang kurang terpuji. Banyak pelajar yang terlibat tawuran, melakukan tindakan kriminal, pencurian, penodongan, penyimpangan seksual, menyalahgunakan obat-obat terlarang dan lain sebagainya. Perbuatan tidak terpuji yang dilakukan oleh pelajar tersebut benar-benar telah meresahkan masyarakat dan merepotkan pihak aparat keamanan. Hal tersebut masih ditambah lagi dengan adanya peningkatan jumlah penganggur yang pada umumnya adalah tamatan pendidikan

Manajemen pendidikan harus dibenahi, profesionalisme pendidik perlu ditingkatkan dan mental serta moral anak didik mutlak harus dibina. Untuk mencapai hal tersebut, peran pendidik sangat diperlukan. Pendidik bertanggung jawab untuk mendidik dan membimbing muridnya. Karena itu, pendidik harus memiliki pengetahuan, keterampilan, dan kecakapan dasar dalam melaksanakan pembelajaran. Pembelajaran pada hakikatnya adalah proses interaksi antara peserta didik dengan lingkungannya, sehingga terjadi perubahan perilaku ke arah yang lebih baik. Dalam interaksi tersebut banyak sekali faktor yang mempengaruhinya, baik faktor internal yang datang dari dalam diri individu, maupun faktor eksternal yang datang dari lingkungan. Dalam pembelajaran, tugas pendidik yang paling utama adalah mengkondisikan lingkungan agar menunjang terjadinya perubahan perilaku bagi peserta didik

Untuk memudahkan pemahaman terhadap filosofi Quantum, dibawah ini terdapat beberapa kata kunci dan definisi Quantum sebagai Interaksi yang mengubah energi menjadi cahaya. Jadi “Quantum Learning” adalah orkestrasi bermacam-macam interaksi yang ada di dalam dan di sekitar momen belajar. Interaksi-interaksi ini mencakup unsurunsur untuk belajar efektif yang mempengaruhi kesuksesan mahasiswa. Interaksi-interaksi ini mengubah kemampuan dan bakat alamiah mahasiswa menjadi cahaya yang akan bermanfaat bagi mereka sendiri dan bagi orang lain. Menurut Deporter memberikan penjelasan tentang pembelajaran Quantum sebagai berikut "Pembelajaran Quantum hampir sama dengan sebuah simfoni". Ada 
banyak unsur yang menjadi pengalaman bermusik. Unsur-unsur tersebut terdiri atas dua kategori yaitu konteks dan isi (contex and content).

Pembelajaran merupakan salah bagian penting dari proses pendidikan formal dalam lingkungan sekolah dimana didalamnya terjadi interaksi antara beberapa komponen pengajaran, yaitu pendidik, isi atau materi pelajaran dan peserta didik. Interaksi antara ketiga komponen itu melibatkan sarana dan prasarana, seperti mengajar, media dan penataan tempat belajar. Sehingga tercipta situasi pembelajaran yang diinginkan sesuai dengan tujuan yang telah direncanakan sebelumnya. Proses belajar mengajar menempuh dua tahapan, yaitu tahapan pertama adalah perencanaan dan tahapan kedua adalah melaksanakan kegiatan pembelajaran termasuk penelitian.

\section{Perencanaan}

pembelajaran terwujud dalam bentuk Satuan Pembelajaran (SP) yang terdiri dari beberapa rencana pelaksanaan kegiatan pembelajaran (RPKP) berisikan kompetensi dasar, hasil belajar, indikator pencapaian, media pembelajaran, kegiatan belajar mengajar, metode, serta penilaian dan jenis tagihan. Sedangkan pelaksanaan pembelajaran adalah pelaksanaan suatu pelajaran pada saat mengajar, yakni interaksi dosen dengan mahasiswa pada saat pengajaran berlangsung.

Quantum learning harus tercermin dalam suatu pelajaran dan pelaksanaan pengajaran. Pembelajaran Quantum learning tercermin dalam isi satuan pembelajaran, sebab satuan pembelajaran pada hakekatnya adalah rencana atau tindakan yang akan dilakukan oleh pendidik pada saat mengajar. Jadi pengajar dalam hal ini harus memikirkan hal-hal yang akan dilakukan serta menuangkan secara tertulis ke dalam satuan pembelajaran. Melalui pembelajaran Quantum, maka pendidik dapat mengubah kelas menjadi "komunitas belajar" yang setiap detailnya telah diubah secara seksama untuk mendukung belajar optimal yaitu dengan bagaimana cara mengatur bangku, menentukan kebijakan kelas, hingga kepada cara merancang pengajaran. Dengan demikian mahasiswa dengan dinamis dapat mengikuti pembelajaran sehingga dunia dosen dengan dunia mahasiswa dapat terjembatani untuk memudahkan pendidik membangun 
jalinan, menyelesaikan bahan pelajaran dengan cepat, membuat hasil belajar lebih melekat, dan memastikan terjadinya pengalihan pengetahuan.

Untuk mewujudkan hal tersebut di atas, pembelajaran Quantum memberikan strategi atau cara-cara efektif untuk meningkatkan partisipasi komponen pembelajaran dengan mengubah keadaan lingkungan belajar untuk mendukung pembelajaran, motivasi dan minat siswa dengan menerapkan kerangka acuan, Rasa kebersamaan dengan menggunakan Delapan Kunci Keunggulan, Daya ingat siswa dengan menggunakan SLIM-n-BIL, Daya dengar siswa dengan mengikuti Prinsip-prinsip Komunikasi Ampuh.

\section{METODE PENELITIAN}

Pelaksanaan penelitian tindakan ini dilakukan dalam dua siklus dengan empat komponen pokok yang juga menunjukkan langkah, yaitu: perencanaan tindakan, (b) pelaksanaan tindakan, (c) observasi dan evaluasi, dan (d) analisis dan refleksi. Hubungan antara keempat komponen tersebut menunjukkan sebuah siklus atau kegiatan berkelanjutan berulang. Subjek penelitian adalah seluruh mahasiswa kelas A semester IV pendidikan matematika IAIN Ambon tahun akademik 2013/2014, dengan jumlah 40 mahasiswa karakteristik kelas ini tidak berbeda dengan kelas paralel lainnya, karena pembagian kelas dilakukan secara acak. Jadi pemilihan kelas sebagai sampel penelitian sematamata karena pertimbangan bahwa peneliti pernah menjadi pengajar di kelas tersebut. Prosedur Penelitian terdiri dari: perencanaan, pelakasanaan, pengamatan, dan refleksi. Teknik pengumpulan data: observasi, tes, pemekriksaan data hasil tes, data situasi belajar, refleksi diri, dan tanggapan mahasiswa. Indikator Kinerja keberhasilan tindakan kelas ini bila terjadi peningkatan skor rata-rata hasil belajar matematika dan perubahan sikap mahasiswa kelas A semester IV pendidikan matematika IAIN Ambon terhadap bahan ajar setelah diberikan tindakan pembelajaran dengan menerapkan pembelajaran Quantum Learning.

\section{HASIL PENELITIAN}

\section{Hasil Tes Akhir Siklus I}

Berdasarkan hasil analisis deskriptif, diperoleh informasi bahwa skor rata-rata hasil belajar mahasiswa kelas $\mathrm{A}$ 
semester IV pendidikan matematika IAIN Ambon setelah pembelajaran melalui Quantum Learning yang dilaksanakan pada Siklus I adalah 7,18 dengan standar deviasi 1,07 dari skor ideal yang mungkin dicapai 10. Ini menunjukkan bahwa secara rata-rata kelas tingkat penguasaan terhadap pokok bahasan ruang dimensi tiga yang diajar pada Siklus I sebesar $72,7 \%$ dari seluruh materi yang diberikan.secara individual, skor yang dicapai responden tersebar dari skor minimum 4,7 dari skor minimum ideal Tabel 1 Distribusi Frekuensi dan Persentase Hasil Belajar mahasiswa pada Siklus I

\begin{tabular}{|c|c|c|c|c|}
\hline No & Skor & Kategori & Frekuensi & Persentase \\
\hline 1. & $0-3,4$ & Sangat Rendah & 0 & 0 \\
2. & $3,5-5,4$ & Rendah & 3 & 7,5 \\
3. & $5,5-6,4$ & Sedang & 8 & 20,0 \\
4. & $6,5-8,4$ & Tinggi & 24 & 60,0 \\
5. & $8,5-10$ & Sangat Tinggi & 5 & 12,5 \\
\hline \multicolumn{6}{|c|}{ Jumlah } & 40 & 100 \\
\hline
\end{tabular}

Berdasarkan skor rata-rata hasil hasil belajar mahasiswa kelas A semester belajar mahasiswa yang diperoleh setelah IV pendidikan matematika IAIN Ambon proses pembelajaran selama Siklus I setelah proses pembelajaran melalui berlangsung yaitu sebesar 7,18 dan setelah dikategorisasikan berdasarkan tabel di atas, diketahui bahwa tingkat penguasaan mahasiswa kelas A semester IV pendidikan matematika IAIN Ambon berada pada kategori tinggi.

\section{Hasil Tes Akhir Siklus II}

Berdasarkan hasil analisis $81 \%$ dari seluruh materi yang deskriptif diperoleh bahwa skor rata-rata diberikan.secara individual, skor yang 
dicapai responden tersebar dari skor Jika skor penguasaan mahasiswa di atas minimum 5,2 dari skor minimum ideal dikelompokkan kedalam lima kategori yang mungkin dicapai 0 sampai dengan maka diperoleh distribusi frekuensi skor skor maksimum 10 dari skor ideal yang seperti ditunjukkan pada Tabel 2 berikut mungkin dicapai 10 dengan rentang 3,9. ini.

Tabel 2 Distribusi Frekuensi dan Persentase Hasil Belajar mahasiswa pada Siklus II

\begin{tabular}{|c|c|c|c|c|}
\hline No & Skor & Kategori & Frekuensi & Persentase \\
\hline 1. & $0-3,4$ & Sangat Rendah & 0 & 0 \\
\hline 2. & $3,5-5,4$ & Rendah & 0 & 0 \\
\hline 3. & $5,5-6,4$ & Sedang & 2 & 5,0 \\
\hline 4. & $6,5-8,4$ & Tinggi & 25 & 62,5 \\
\hline 5. & $8,5-10$ & Sangat Tinggi & 13 & 32,5 \\
\hline \multicolumn{3}{|c|}{ Jumlah } & 40 & 100 \\
\hline
\end{tabular}

Berdasarkan skor rata-rata hasil

belajar mahasiswa yang diperoleh setelah proses belajar mengajar selama Siklus II Perubahan sikap mahasiswa dalam proses pembelajaran

berlangsung yaitu sebesar 8,17 dan setelah

Siklus I

dikategorisasikan berdasarkan tabel di atas, diketahui bahwa tingkat penguasaan mahasiswa kelas A semester IV pendidikan matematika IAIN Ambon berada pada kategori tinggi.

\section{Hasil Analisis Kualitatif}

Setelah hasil analisis kuantitatif diperoleh maka hasil dapat dirumuskan untuk dinyatakan secara kualitatif. Rumusan yang dimaksud tidak lain hanyalah merupakan refleksi kegiatan selama penerapan pembelajaran Quantum Learning. Adapun refleksi yang terjadi selama proses pembelajaran dari setiap siklus adalah sebagai berikut:

Dari awal penelitian berlangsung hingga berakhirnya Siklus I tercatat sejumlah perubahan yang terjadi pada mahasiswa yaitu:Pemberian tes visualauditorial-kinestetik (V-A-K) untuk mengidentifikasi gaya belajar mahasiswa sebagai modalitasnya dalam belajar, telah memicu mahasiswa memaksimalkan gaya belajar mereka masing-masing; Partisipasi mahasiswa dalam mengubah lingkungan belajar untuk mendukung pembelajaran Quantum Learning ada peningkatan; Dengan memberi pengakuan terhadap segala usaha mahasiswa, telah meningkatkan motivasi mahasiswa untuk menjawab soal yang diberikan utamanya soal-soal yang dikerjakan di papan tulis; 
Suasana belajar yang menggembirakan dengan dukungan lingkungan yang cukup kondusif, mendorong perhatian mahasiswa untuk giat belajar dengan memperbaiki kesalahan jawaban latihan di kelas; Rasa percaya atas kemampuan sendiri secara berangsur terbangun pada diri mahasiswa; Pengalaman belajar yang menyenangkan telah mengajak mahasiswa ke dalam proses belajar yang dinamis dan tak terlupakan.

\section{Siklus II}

Dari awal penelitian berlangsung hingga berakhirnya Siklus II tercatat sejumlah perubahan yang terjadi pada mahasiswa yaitu: Adanya keinginan mahasiswa untuk menyempurnakan penataan kelas seperti yang telah dilakukan pada siklus sebelumnya agar komunitas belajar tercipta untuk mendukung belajar yang optimal; Sikap antusias mahasiswa terhadap proses belajar mengajar ada peningkata; Pengakuan terhadap segala usaha mahasiswa, telah meningkatkan motivasi siwa untuk menjawab soal yang diberikan utamanya soal-soal yang dikerjakan di papan tulis; Pada siklus ini mahasiswa yang masih memerlukan bimbingan dalam mengerjakan soal latihan yaitu pada awal- awal pertemuan berkisar 4-9 orang, tetapi diakhir siklus tinggal beberapa orang berkisar 2-3 orang dan Pada siklus ini, kemampuan mahasiswa mengerjakan soal di papan tulis dengan benar mengalami peningkatan yang signifikan; Frekuensi kehadiran mahasiswa pada siklus ini tergolong tinggi, karena hanya sekitar 1-3 orang yang tidak hadir selama pelaksanaan pembelajaran pada siklus ini, itu pun karena alasan tertentu.

\section{PEMBAHASAN}

\section{Refleksi Siklus I}

Berdasarkan hasil observasi yang menjadi rekaman pelaksanaan tindakan pada Siklus I dapat dikemukakan perubahan-perubahan sikap yang terjadi di dalam realisasi tindakan terhadap proses aktivitas belajar di kelas selama kegiatan berlangsung. Sejak pertemuan pertama pada minggu pertama, sebagian besar mahasiswa sudah menunjukkan sikap antusias untuk mengikuti pelajaran. Seluruh mahasiswa kelas A semester IV pendidikan matematika IAIN Ambon sudah kenal baik dengan penulis dan metode mengajarnya, karena pada semester sebelumnya mereka diajar oleh penulis 
Setelah kegiatan berlangsung sampai pertemuan terakhir Siklus I sudah nampak perubahan yang terjadi, hal ini ditunjukkan dengan minimnya mahasiswa melakukan kegiatan yang tidak berhubungan dengan proses pembelajaran. Mahasiswa menunjukkan antusias untuk mengikuti pelajaran, namun beberapa dari mereka masih ada yang berusaha melihat pekerjaan temannya saat diberi tugas mandiri.

Soal-soal latihan pada buku paket yang dimiliki mahasiswa dibahas satu persatu jika sebagian besar dari mereka telah mengerjakan, penulis lalu memberi kesempatan kepada mahasiswa untuk menyelesaikannya di papan tulis. Jika pembahasan soal-soal latihan di kelas tidak selesai, maka mahasiswa mengerjakan soal-soal latihan di rumah sebagai tugas mereka.

Keberadaan buku paket yang dimiliki oleh mahasiswa sangat mendukung kelancaran proses pembelajaran, sehingga penulis dapat memberi tugas dari buku tersebut. Namun, karena tidak sering, mereka terasa berat jika diberikan pekerjaan rumah dengan jumlah banyak. Tetapi, setelah diberikan pengertian bahwa hal tersebut dilakukan demi kebaikan mereka, mahasiswa mulai menunjukkan perubahan positif, hal ini dilihat dari hasil refleksi dan tanggapan mahasiswa dimana mereka mulai menyenangi pembelajaran seperti itu, aktivitas yang dilakukan dalam Quantum Learning seperti membuat poster afirmasi, chart rumus-rumus, dan rangkuman materi pelajaran pada buku tulis atau di dalam kamar mereka, mereka anggap menarik karena dimanapun baik di rumah dan di kelas dan kapanpun mereka dapat belajar tanpa harus membuka buku pelajaran mereka.

Hasil refleksi tersebut menjadi dasar acuan dilanjutkannya pelaksanaan tindakan ke Siklus II dengan mengupayakan peningkatan kualitas belajar mahasiswa melalui Quantum Learning.

\section{Refleksi Siklus II}

Berdasarkan hasil observasi yang menjadi rekaman pelaksanaan tindakan pada Siklus II dapat dikemukakan perubahan-perubahan sikap yang terjadi didalam realisasi tindakan terhadap proses aktivitas belajar di kelas selama kegiatan berlangsung. Sikap mahasiswa sudah menunjukkan sikap antusisas untuk mengikuti pelajaran bahkan sebagian 
besar dari mereka sudah mengerjakan soal latihan suatu pokok bahasan sebelum pokok bahasan tersebut dibahas di kelas.

Frekuensi kehadiran mahasiswa selama mengikuti kegiatan proses pembelajaran sampai akhir pertemuan Siklus II menggambarkan bahwa minat dan motivasi belajar mahasiswa mengalami peningkatan, disamping itu motivasi positif terbangun dikalangan mahasiswa dengan hilangnya rasa rendah diri mahasiswa akibat cacat belajar dan berprestasi rendah sehingga menghilangkan sekat yang dapat menghambat proses pembelajaran. Citra diri mahasiswa yang semula pesimis akan kemampuan yang dimilikinya kini menunjukkan optimisme yang ditunjukkan dengan hasil pekerjaan dari soal-soal tugas yang diberikan hampir semua mahasiswa mengerjakan secara mandiri di rumah.

Optimalnya peran modalitas belajar yang telah terlebih dahulu diidentifikasi dikalangan mahasiswa semakin meningkatkan kualitas belajar mereka berdampak kepada meningkatnya kemampuan mahasiswa dalam menerima pelajaran. Dengan demikian dapat dikatakan bahwa pembelajaran pada Siklus II ini semakin baik.

\section{KESIMPULAN}

Secara kuantitatif, terjadi peningkatan hasil belajar kajian matematika SMA mahasiswa kelas A semester IV pendidikan matematika IAIN Ambon dari kategori rendah dengan skor rata-rata 5,40 sebelum adanya pemberian perlakuan atau penerapan pembelajaran Quantum Learning, menjadi kategori tinggi dengan skor rata-rata 7,18 pada Siklus I dan lebih meningkat lagi dengan skor rata-rata 8,17 pada Siklus II setelah diterapkan Quantum Learning. Secara kualitatif, terjadi perubahan sikap. Mahasiswa menunjukkan sikap antusias untuk mengikuti pelajaran, minat dan motivasi belajar mahasiswa mengalami peningkatan, hilangnya rasa rendah diri akibat berprestasi rendah sehingga menghilangkan sekat yang dapat menghambat proses pembelajaran, citra diri mahasiswa kini semakin optimis akan kemampuan yang mereka miliki, optimisme itu ditunjukkan mahasiswa dengan mengerjakan secara mandiri tugasnya di rumah. Modalitas belajar yang telah diidentifikasi sebelumnya semakin 
meningkatkan kualitas belajar mahasiswa berdampak kepada meningkatnya kemampuan mahasiswa dalam mengikuti pembelajaran. Dengan demikian dapat dikatakan bahwa pembelajaran pada akhir siklus semakin baik.

\section{DAFTAR PUSTAKA}

Arikunto, S. 2002. Dasar-Dasar Evaluasi Pendidikan. Bumi Aksara. Jakarta

Arikunto, S. 2002. Prosedur Penelitian Suatu Pendekatan Praktek. Rineka Cipta. Jakarta

Deporter, Bobbi. Mark R. \& Sarah SingerNourie. 2003. Quantum Teaching Mempraktikkan Quantum Learning di Ruang-ruang Kelas. Kaifa. Bandung

Deporter, Bobbi \& Mike H. 2002. Quantum Learning Membiasakan Belajar Nyaman dan Menyenangkan. Kaifa. Bandung

Mulyasa, E. 2002. Kurikulum Berbasis Kompetensi Konsep, Karakteristik, dan Implementasi. PT. Remaja Rosdakarya. Bandungg

Nata, Abuddin. 2003. Manajemen Pendidikan Mengatasi Kelemahan Pendidikan Islam Di Indonesia. Prenada Media. Jakarta

Sugiyono. 1999. Statistika untuk Penelitian. CV. Alfabeta. Bandung

Suherman. H, Erman. dkk. 2003. Strategi Pembelajaran Matematika

Kontemporer. JICA. Universitas Pendidikan Indonesia
Tim Pelatih Lemlit UNM. 2003. Penelitian Tindakan Kelas. Lembaga Penelitian Universitas Negeri Makassar. Makassar 